$$
\mathrm{CH}_{2} \mathrm{Cl}-\mathrm{CH}(\mathrm{OH})-\mathrm{CH}_{2} \mathrm{Cl}
$$

was produced; this was oxidised by potassium dichromate and sulphuric acid, to dichloracetone,

$$
\mathrm{CH}_{2} \mathrm{Cl}-\mathrm{CO}-\mathrm{CH}_{2} \mathrm{Cl} \text {, }
$$

which, when acted on by concentrated hydrocyanic acid, yielded dichloracetone cyanhydrin,

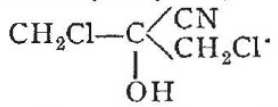

The acid corresponding to this cyanhydrin having been produced by saponifying with hydrochloric acid, the sodium salt of this acid, viz.,

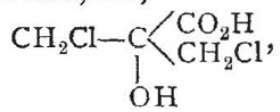

was treated with potassium cyanide, whereby a dicyanide,

$$
\begin{gathered}
\mathrm{CH}_{2} \mathrm{CN}-\underset{\mathrm{OH}}{\mathrm{C}}\left\langle\mathrm{CH}_{2} \mathrm{H}\right. \\
\mathrm{CH}_{2} \mathrm{CN} \\
\mathrm{CH}
\end{gathered}
$$

was produced. When decomposed by hydrochloric acid, this dicyanide yielded citric acid, in all respects identical with that obtained from the lemon and other fruits. The generally accepted structural formula for citric acid, viz.,

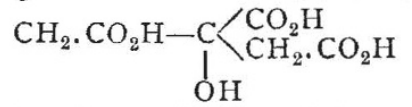

is confirmed by the synthesis of Grimaux and Adam. Glycerin may be prepared from trichlorhydrin,

$$
\mathrm{CH}_{2} \mathrm{Cl}-\mathrm{CHCl}-\mathrm{CH}_{2} \mathrm{Cl} \text {, }
$$

which is itself obtained by the action of chlorine in daylight on propylenic chloride,

$$
\mathrm{CH}_{3}-\mathrm{CHCl}-\mathrm{CH}_{2} \mathrm{Cl} \text {, }
$$

one of the products of the chlorination of propylene, $\mathrm{C}_{3} \mathrm{H}_{6}$. Finally this hydrocarbon, propylene, may be produced by passing a mixture of carbon monoxide and marsh gas through a red-hot tube. Inasmuch as carbon monoxide and marsh gas are easily built up from carbon, hydrogen, and oxygen, the synthesis of citric acid from these three elements is now an accomplished fact.

In connection with this synthesis, it is worthy of remark that in the last number of the Berlin Berichte, Kekule announces that he has been working at the same subject, but by a totally different method. Kekule's work is not sufficiently advanced for him to say positively that his method of synthesis is successful, but he feels justified in saying that very probably the process adopted by him has resulted in the formation of citric acid.

$$
\text { M. M. P. M. }
$$

\section{PLANTS FROM LAKE NYASSA AND LAKE TANGANYIKA}

$M^{R}$. THOMSON, who has recently returned from the $M$ expedition of the Royal Geographical Society to Central Africa, has brought to Kew a considerable collection of plants from the plateaux round Lake Nyassa and Lake Tanganyika. The plants from an elevation of 6,000 to 8,000 feet above sea-level contain a large proportion of Cape and characteristically temperate types. Amongst the former are the well-known Dierama (Sparaxis) pendula, Scilla rigidifolia, Buphane toxicaria (the great poison bulb of Natal and the Transvaal), a fine Morea with a long tube and bright purple flowers as large as those of Iris fatidissima, a Gladiolus, a Pelargonium, more than one species of Gnidia and Helichrysum, and a proteaceous shrub (probably Faurea, which extends to Abyssynia) with large heads of flowers. Of characteristically temperate types there are species of Geranium, Kumex, Cerastium, Coalamintha, and a Scabiosa, perhaps identical with our European and English $S$. Columbarice. Upon the plateaux below 6,000 feet the vegetation assumes a sub-tropical character. Here he met with a tree-fern of the genus Cyathea, 'A gauria salicifolia, Hook, fil, an ericaceous shrub common to Bourbon, Madagascar, and the Cameroons, representatives of Mimulopsis, Hibiscus, Clematis, Phyllanthus, Gerbera, Smithia, Acalypha, Pentas, Thunbergia, Buchnera, Striga, a shrubby Spermacoce, a curious Loranthus with broad leaves and tubular flowers densely clothed with yellow hairs, Hypoxis Villosa, several fine Dombeyas, Vernonias, and Combretums, a genus of Hedysarea with flowers in heads like those of the hop, and a curious broad-leaved Euphorbia, with very large hand-like glands to the involucre. The specimens are well selected and excellently dried. It is probable that nearly all of them are in a condition in which their botanical position can be settled, and that although upon a hasty glance there do not seem to be any strongly-marked new generic "types, a good many of the species will prove new to science. The marked northern extension of the Cape flora at comparatively high elevations in Central Africa is a fact of importance. It quite supports the theory that that flora is of great antiquity, and that what exists of it at the Cape is only a survival from a period when it was probably far more extensively diffused, though perhaps less highly specialised. It is much to be desired that travellers in Central Africa would do all in their power to collect dried specimens of the vegetation of elevations above 6,000 feet.

\section{GRAHAM BELL'S EXPERIMENTS IN BINAURAL AUDITION}

PROF. GRAHAM BELL has published in the American (quarterly) Journal of Otology a memoir on some experiments relating to binaural audition, read by him last autumn at the session of the American Association for the Advancement of Science. Some of his observations confirm the work of previous observers, but are of additional value in affording a more systematic examination of some of the phenomena than has hitherto been attempted. The following summary of the results obtained by him will therefore be of some interest.

When we close one ear and listen to sounds through the other only, there seems to be a onesidedness about them, as there is about objects perceived by one eye. When both ears are employed simultaneously a sort of stereoscopic effect of audition is perceived. Sounds assume a "solidity" which was not perceptible so long as one ear alone was employed. The difference between monaural and binaural audition is especially well marked when we attempt to decide by ear the locality of a particular sound. Whatever power a single ear may possess of determining the direction of a source of sound, both ears are certainly much more effective for this purpose.

The following experiment, designed to produce artificially the stereophonic phenomena of binaural audition, was therefore devised by Prof. Bell while in this country in 1878 . Four telephones were arranged, as in the figure. The telephones $A$ and $B$ in one room; C and D in another. The mouthpieces of $A$ and $B$ were turned away from one another like the auricles of a person's ears, and the diaphragms were about as far apart as the tympana of the two ears. The expectation was that a person holding $C$ and $D$ to his ears should not simply hear speech when any one was talking near $A$ and $B$, but that he should be able to perceive the direction of the speaker's voice relatively to $A$ and $B$. In fact, the listener's ears were, as it were, electrically prolonged to $\mathrm{A}$ and $\mathrm{B}$ respectively. The sensations produced were decidedly novel; but not exactly such as had been expected. Using various sources of sound-speaking, ringing a loud dinner-bell in various parts of the room, \&c.- it was found that the location of the sound could be determined to a limited extent. The 